MACHINE BUILDING

МАШИНОБУДУВАННЯ

UDC 621.742.486

L. Solonenko ${ }^{1}$, PhD, Assoc. Prof.,

S. Repiakh², DSc, Prof.,

K. Uzlov ${ }^{2}$, DSc, Prof.,

T. Kimstach ${ }^{2}$

${ }^{1}$ Odessa National Polytechnic University, 1 Shevchenko Ave., Odessa, Ukraine, 65044; e-mail: solonenkoli14@gmail.com

${ }^{2}$ National Metallurgical Academy of Ukraine, Gagarin Ave., Dnipro, Ukraine, 49600

\title{
CRUSHING CHARACTER OF SAND-SODIUM-SILICATE MIXTURES STRUCTURED BY STEAM-MICROWAVE TREATMENT
}

Л.I. Солоненко, С.I. Реn'яx, К.I. Узлов, Т.В. Кимстач. Характер руйнування піщано-рідкоскляних сумішей, що структуруванні паро-мікрохвильовою обробкою. На сьогоднішній день 3 числа відомих способів структурування піщанорідкоскляних сумішей найменш дослідженим, але найбільш перспективним, $є$ спосіб паро-мікрохвильового затвердіння. Мета роботи - встановити характер руйнування піщано- рідкоскляних сумішей, структурованих за способом паро-мікрохвильового затвердіння. У роботі використовували кварцовий пісок, плакований натрієвим рідким склом. Структурування суміші (плакованого піску) проводили мікрохвильовим випромінюванням при номінальній потужності магнетрона 700 Вт і частотою випромінювання 2,45 ГГц, використовуючи наважку води в суміші масою 1 г. Структури зразків суміші досліджували на растровому електронному та оптичному мікроскопі. Встановлено, що зі збільшенням масового вмісту рідкого скла для плакування кварцового піску від 0,5 до $6 \%$ (за масою), а також зі збільшенням тривалості обробки суміші способом паро-мікрохвильового затвердіння межа міцності суміші при стисненні зростає по залежності близької до статечної. Характер руйнування структурованої суміші, при цьому не залежить від вмісту рідкого скла, який пішов на плакування кварцового піску, але залежить від тривалості паро-мікрохвильового затвердіння зі збільшенням якого переходить від адгезійного до змішаного або від адгезійного до змішаного і когезійного.

Ключові слова: піщано-рідкоскляна суміш, рідке скло, паро-мікрохвильове затвердіння, адгезія, когезія, міцність

L. Solonenko, S. Repiakh, K. Uzlov, T. Kimstach. Crushing character of sand-sodium-silicate mixtures structured by steammicrowave treatment. At the present, from among the known methods of sand-sodium-silicate mixtures structuring, the least studied, but the most promising, is the method of steam-microwave solidification. Among unexplored elements of steam-microwave solidification method is nature of mixtures destruction. This is especially important for determining the ways to increase the sand-sodium-silicate casting molds and cores strength before pouring and lowering their strength by the time when casting should be knocked out the mold and the core from cast product. Knowledge about mixture destruction nature is also necessary for appropriate technical solutions elaboration concerning sand regeneration. In this regard, the purpose of the present work has to be nature of sand-sodium-silicate mixtures structured by steammicrowave solidification method destruction establishing. Quartz sand cladded with sodium-silicate solute has been used in the present investigation. Mixture (cladded sand) structuring has been carried out by microwave radiation at nominal magnetron power of $700 \mathrm{~W}$ and radiation frequency of $2.45 \mathrm{GHz}$ in area of standing waves. To cladded sand structuring, $1 \mathrm{~g}$ water portion has been added, which has been placed in bottom of container in which mixture has been microwave treated. To make decision on mixture destruction nature, images of structured mixtures destruction places within one grain (sand grain), which are typical for adhesive and cohesive character of destruction, obtained with scanning electron microscope have been used. It has been found that with sodium-silicate solute for quartz sand cladding mass content from 0.5 to $6 \%$ (by weight) increasing, as well as with mixture processing by the method of steam-microwave solidification duration increasing, mixture compression ultimate strength increases according to dependence closed to exponential. Character of structured mixture destruction, in this case, is not depend on sodium-silicate solute used for quartz sand cladding content, but depends on steam-microwave solidification duration. With its time increasing it changes from adhesive to mix or from adhesive to mixed and cohesive.

Keywords: sand-sodium-silicate mixture, sodium silicate solute, steam-microwave solidification, adhesion, cohesion, strength

\section{Introduction}

Casting molds and cores (CMC) structuring by thermal drying is consequence of certain heat- and mass- transferring processes realization in them. This results the new structures appearance at the binder material contacts boundaries and mixture refractory filler grains, binder material cuffs between adjacent filler grains appearance, binder material compaction and solidification in cuffs, etc [1 -6]. 
Phases cyclic arrangement in structure of such mixtures causes the fact that, finally, their strength is determined by the value of both - binder adhesion forces to the surface of sand grains $\left(\sigma_{\mathrm{ADH}}\right)$ and cohesion value $\left(\sigma_{\mathrm{COH}}\right)$ - strength of both: CMC binder and refractory filler grains $[7,8]$. In the first approximation, depending on $\sigma_{\mathrm{ADH}} / \sigma_{\mathrm{COH}}$ ratio value, the nature of this or that mixture destruction could be estimated. Moreover, for some types of mixtures, strictly specific destruction character is inherent. In particular, authors [9] CMC, according to destruction nature, distinguish sandy-clay mixtures as typical, in which destruction is exclusively adhesive in nature $\left(\sigma_{\mathrm{ADH}} / \sigma_{\mathrm{COH}}>1\right)$, sand-resin mixtures are of cohesive nature $\left(\sigma_{\mathrm{ADH}} / \sigma_{\mathrm{COH}}<1\right)$, sand-sodium-silicate mixtures - are of mixed (adhesivecohesive) character $\left(\sigma_{\mathrm{ADH}} / \sigma_{\mathrm{COH}} \cong 1\right)$.

\section{Recent publications analysis}

Many scientists and researchers have been involved in theoretical calculations of structured CMC ultimate strength. The best known are theoretical strength calculations results of Lyass A.M. [10], Zykova A.P. and Minaev G.I. [11] for mixed nature of CMC destruction, of Degtyarenko G.I. and Stolyar E.A. [2] for cohesive destruction nature.

These theoretical studies general result is the statement that with density of binder material dry residue increasing, tensile strength of CMC decreases, and with binder content and mixture specific density increasing, CMC tensile strength increases. At the same time, in these authors' calculations, there are parameters, which real values for structured CMC are not constant and varying in very wide range. For this reason, present studies have outstanding theoretical meaning.

Velikanov G.F. and Brechko A.A. in [12] presented simplified formula for CMC compression ultimate strength calculation:

$$
\sigma_{\mathrm{COMP}}=\sigma_{\mathrm{COH}}\left(\sigma_{\mathrm{ADH}}\right) \cdot N_{S} \cdot S \text {, }
$$

where $\sigma_{\mathrm{ADH}}$ - adhesive strength;

$\sigma_{\mathrm{COH}}-$ cohesive strength;

$N_{S}$ - number of contacts per area unit;

$S$ - contact area.

Formula (1) takes into account contacts (cuffs) number and area, with increase in which strength increases, and indicates its dependence on sand fractional composition and binder amount used in mixture. But formula (1) does not take into account the effect of structuring method on adhesive and cohesive strength values, which has significant influence on CMC strength and follows from histogram in Fig. 1, based on [2] data.

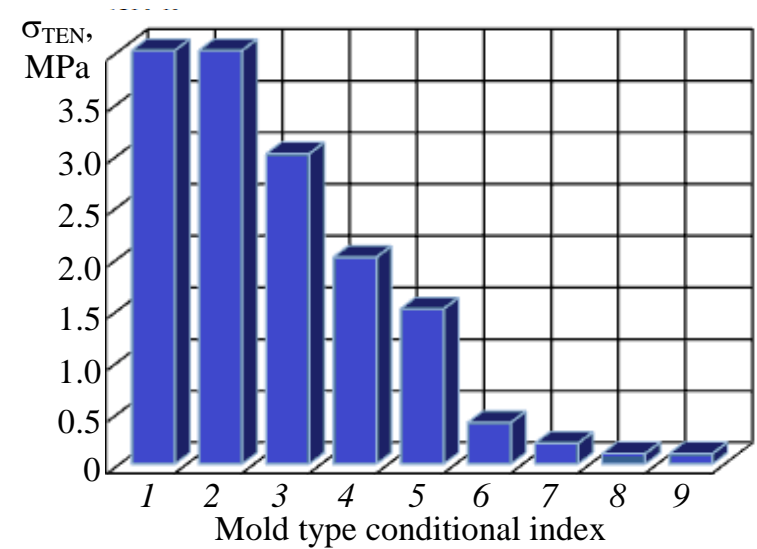

Fig. 1. Ultimate tensile strength depending on mold material: 1 - graphite, 2 - shell, 3 - ceramic (investment), 4 - frozen, 5 - sand-resin, 6 - sandsodium-silicate, 7 - sand-clay; 8 - magnetic, 9 - vacuum-film
Problem establishing. To date, among the known methods of sand-sodium-silicate mixtures (SSSM) structuring, the least studied, but the most promising is steam-microwave solidification (SMS) method. But at present there are no data on SSSM, structured by the SMS-process, destruction nature. Effect of sodium silicate solute (SSS) mass content in mixture and its structuring time have not been studied.

Purpose - to establish SSSM structured by SMS-process destruction character.

Investigation tasks - to investigate the fractography of SSSM structured by SMS method fracture surface, to determine the influence of microwave radiation treatment duration and sodium silicate solute, which has been cladded with quartz sand, mass content on the nature of such mixtures destruction. 
Research object. Structure of sand-sodium-silicate mixtures, structured by the PMO method, fracture surfaces.

\section{Materials and methodology}

Quartz sand with clay content of less than $0.5 \%$ (by weight) and with predominant grain size of $0.23 \mathrm{~mm}$ has been used in this study. For use, sand has been cladded with sodium silicate solute (GOST 13078-81) with silicate modulus of 2.8...3.0 and specific density of $1.43 \ldots 1.46 \mathrm{~g} / \mathrm{cm}^{3}$. Mixture structuring has been carried out by microwave radiation at nominal magnetron power of $700 \mathrm{~W}$ and radiation frequency of $2.45 \mathrm{GHz}$ using water portion in mixture of $1 \mathrm{~g}$. Ultimate strength in compression $\left(\sigma_{\mathrm{COMP}}\right)$, tensile $\left(\sigma_{\mathrm{TEN}}\right)$ and static bending $\left(\sigma_{\mathrm{BEND}}\right)$ of structured mixtures have been determined according to generally accepted methods on samples of structured mixture with diameter of $\varnothing 30 \times 30 \mathrm{~mm}$ in compression tests, on samples of beam type with dimensions $15 \times 15 \times 160 \mathrm{~mm}$ under static bending and on specimenseights in tension tests according to GOST 23409.7-78. Samples have been tested on LRu-2e device. Gas permeability of structured mixtures has been determined on samples with diameter of $\varnothing 50 \times 50 \mathrm{~mm}$ using bell-type device model 04315 according to GOST 23409.6-78.

Samples broken surfaces structural peculiarities have been investigated according to fractography analysis results of fractures with scanning electron microscope SEM-106 I at accelerating voltage from 20 to $30 \mathrm{kV}$ and beam current from $4 \mu \mathrm{A}$ to $30 \mu \mathrm{A}$ in secondary electrons with probe spot diameter from 1000 to $200 \mathrm{~nm}$ and with MBS-10 optical microscope.

As standard samples for fracture sites images of structured mixtures identification within one grain (sand grain) obtained with scanning microscope at magnification $\times 100$ have been used. Fractography of these microstructures is shown in Fig. 2.
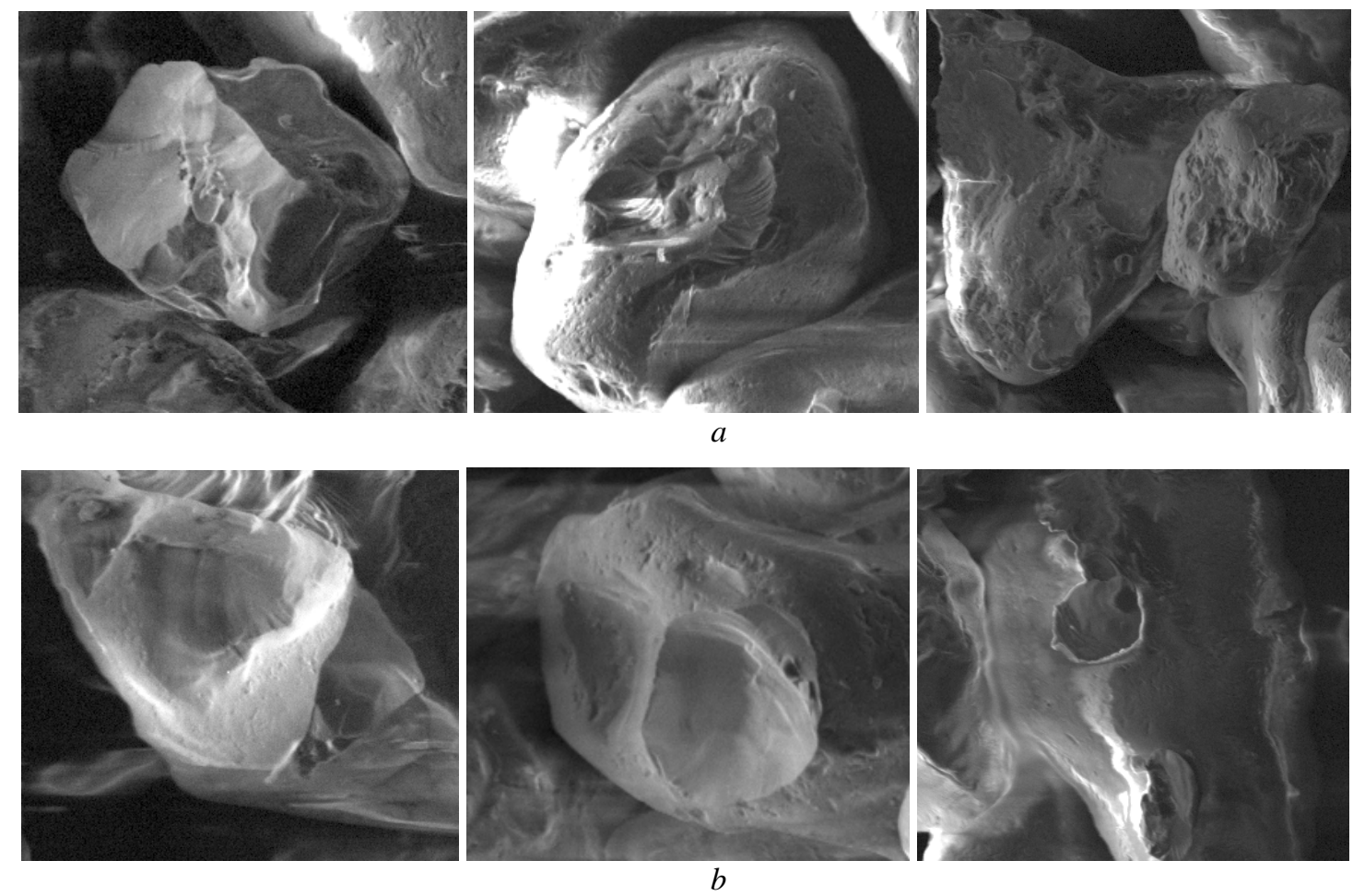

Fig. 2. Fracture surfaces appearance of sodium silicate cuffs with purely cohesive $(a)$ and purely adhesive $(b)$ destruction character, $\times 100$

\section{Investigation results}

Values of ultimate strength in compression $\left(\sigma_{\mathrm{COMP}}\right)$, tensile $\left(\sigma_{\mathrm{TEN}}\right)$ and bending $\left(\sigma_{\mathrm{BEND}}\right)$, as well as their ratios for SSSM, structured by the SMS-process, are given in Table 1. 


\section{Table 1}

Values of ultimate strength in compression $\left(\sigma_{\mathrm{COMP}}\right)$, tensile $\left(\sigma_{\mathrm{TEN}}\right)$ and bending $\left(\sigma_{\mathrm{BEND}}\right)$, as well as their ratios for SSSM, structured by SMS-process

\begin{tabular}{|c|c|c|c|c|c|c|c|c|c|c|}
\hline \multirow[b]{2}{*}{$\begin{array}{l}\text { No } \\
\text { in } \\
\text { order }\end{array}$} & \multirow{2}{*}{ 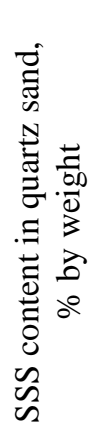 } & \multirow{2}{*}{ 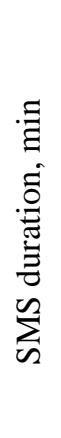 } & \multirow{2}{*}{ 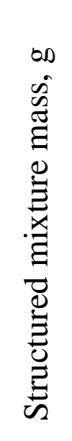 } & $\sigma_{\mathrm{COMP}}$ & $\sigma_{\mathrm{TEN}}$ & $\sigma_{\text {BEND }}$ & \multirow[b]{2}{*}{$\frac{\sigma_{\mathrm{COMP}}}{\sigma_{\mathrm{TEN}}}$} & \multirow[b]{2}{*}{$\frac{\sigma_{\text {COMP }}}{\sigma_{\text {BEND }}}$} & \multicolumn{2}{|c|}{$\begin{array}{l}\text { Ultimate strength rela- } \\
\text { tive deviation in calcula- } \\
\text { tion, \% }\end{array}$} \\
\hline & & & & \multicolumn{3}{|c|}{$\mathrm{MPa}$} & & & $\Delta_{\mathrm{TEN}}$ & $\Delta_{\mathrm{BEND}}$ \\
\hline 1 & 0.5 & 2 & 400 & 0.82 & 0.15 & 0.22 & 5.51 & 3.77 & 1.50 & -1.28 \\
\hline 2 & 0.5 & 3 & 400 & 1.21 & 0.21 & 0.33 & 5.74 & 3.62 & -3.82 & 0.36 \\
\hline 3 & 0.5 & 4 & 500 & 1.47 & 0.27 & 0.41 & 5.44 & 3.55 & 1.90 & 2.57 \\
\hline 4 & 0.5 & 4 & 550 & 1.52 & 0.28 & 0.41 & 5.49 & 3.72 & 2.19 & -0.74 \\
\hline 5 & 1.0 & 2 & 400 & 1.50 & 0.27 & 0.39 & 5.55 & 3.81 & -0.10 & -4.52 \\
\hline 6 & 1.0 & 4 & 550 & 3.02 & 0.56 & 0.81 & 5.37 & 3.71 & 2.83 & -1.32 \\
\hline 7 & 1.5 & 2 & 500 & 2.10 & 0.38 & 0.58 & 5.59 & 3.65 & 0.43 & 1.61 \\
\hline 8 & 1.5 & 3 & 500 & 3.72 & 0.68 & 1.00 & 5.5 & 3.73 & 1.43 & -1.09 \\
\hline 9 & 1.5 & 4 & 500 & 3.99 & 0.73 & 1.08 & 5.48 & 3.69 & 1.52 & -0.39 \\
\hline 10 & 2.0 & 2 & 300 & 2.65 & 0.48 & 0.74 & 5.48 & 3.58 & 0.53 & 2.69 \\
\hline 11 & 2.0 & 3 & 600 & 4.33 & 0.78 & 1.17 & 5.58 & 3.69 & -0.02 & -0.57 \\
\hline 12 & 2.0 & 4 & 400 & 4.71 & 0.84 & 1.28 & 5.61 & 3.69 & -1.03 & 0.01 \\
\hline 13 & 2.5 & 2 & 300 & 2.90 & 0.56 & 0.78 & 5.22 & 3.72 & 6.69 & -1.03 \\
\hline 14 & 2.5 & 3 & 400 & 4.61 & 0.82 & 1.25 & 5.64 & 3.70 & -1.30 & -0.22 \\
\hline 15 & 2.5 & 4 & 500 & 5.12 & 0.90 & 1.40 & 5.68 & 3.67 & -2.50 & 0.62 \\
\hline 16 & 2.5 & 4 & 500 & 4.97 & 0.90 & 1.35 & 5.52 & 3.69 & 0.50 & -0.04 \\
\hline 17 & 3.0 & 2 & 500 & 3.15 & 0.57 & 0.84 & 5.53 & 3.77 & 0.43 & -1.90 \\
\hline 18 & 3.0 & 3 & 900 & 4.85 & 0.87 & 1.32 & 5.55 & 3.68 & -0.45 & 0.16 \\
\hline 19 & 3.0 & 4 & 700 & 5.22 & 0.93 & 1.47 & 5.61 & 3.55 & -1.13 & 3.50 \\
\hline 20 & 4.0 & 2 & 700 & 3.95 & 0.72 & 1.12 & 5.46 & 3.52 & 1.15 & 4.16 \\
\hline 21 & 4.0 & 3 & 700 & 5.03 & 0.94 & 1.37 & 5.33 & 3.66 & 3.58 & 0.23 \\
\hline 22 & 4.0 & 4 & 500 & 5.55 & 0.96 & 1.50 & 5.77 & 3.70 & -4.17 & -0.54 \\
\hline 23 & 6.0 & 2 & 700 & 4.40 & 0.81 & 1.18 & 5.43 & 3.74 & 2.12 & -1.33 \\
\hline 24 & 6.0 & 3 & 400 & 5.17 & 0.89 & 1.40 & 5.81 & 3.69 & -4.67 & -0.35 \\
\hline 25 & 6.0 & 4 & 500 & 5.81 & 1,00 & 1.54 & 5.79 & 3.78 & -4.68 & -2.52 \\
\hline
\end{tabular}

According to Table 1 data, average values of ratios are $\sigma_{\mathrm{COMP}} / \sigma_{\mathrm{TEN}}=5.55, \sigma_{\mathrm{COMP}} / \sigma_{\mathrm{BEND}}=3.68$, and values of relative deviations of $\sigma_{\mathrm{TEN}}$ and $\sigma_{\mathrm{BEND}}$ calculations, using these coefficients, respectively, does not exceed 7 and $5 \%$. This means that by determining, for example, SSSM structured according to the SMS process value of ultimate compressive strength, it is possible with a high degree of reliability for engineering calculations to calculate its tensile and static bending strength. Based on obtained ratios and relatively small values of deviations between studied mixtures strength indicators, to determine mixtures destruction characters, compressive strength values have been used. Such decision has been explained by the fact that among strength indicators presented in table, exactly results of multiply repeated experimental determination of compressive strength have been characterized by smallest obtained values "scattering". 
Dependences of SSSM structured by SMS-process ultimate strength in compression on duration of microwave treatment and on SSS mass content used for quartz sand cladding are shown in Fig. 3.

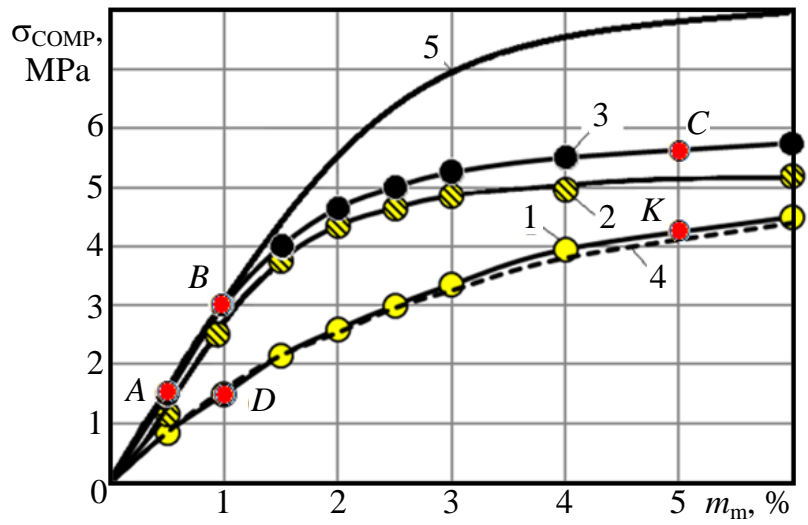

Fig. 3. Dependences of SSSM solidified by SMS-process ultimate strength in compression on WC used for quartz sand cladding mass content and on structuring time: 1 - $2 \mathrm{~min} ; 2-3 \mathrm{~min} ; 3$ - 4 min; 4 - ultimate compressive strength with mixture adhesive fracture; 5 - ultimate compressive strength with mixture cohesive fracture

Curves 4 and 5 (see Fig. 3) have been plotted according to theoretical calculations results presented [13] in non-relative coordinate system and are purely qualitative in mixture ultimate strength changing vs. binder content and mixtures destruction character.

From dependences in Figure 3 analysis, it follows that with SSS mass content from 0 to $6 \%$ increasing, as well as microwave radiation duration increasing, mixture ultimate strength in compression increases according to dependence close to exponential law. At the same time, regardless of SSS content used for quartz sand cladding, mixture processing according to SMS-process for 2 minutes leads to such mixtures destruction per adhesive mechanism. At the same time, mixture processing according to SMS-process for 3 and 4 minutes with SSS content of up to $1.5 \%$ leads to such mixtures destruction per cohesive mechanism. In all other cases there is mixed (adhesive-cohesive) structured mixtures destruction character. It should also be noted that cladded quartz sand structuring at least with SSS content of 0.5 to $2.5 \%$ allows obtaining structured mixtures with ultimate strength in compression level sufficient for their using as CMC. Reason for mixtures structured by SMS method such high strength properties, comparing to other structuring methods, is, apparently, dense and more perfect structure of sodium silicate cuffs between mixture sand grains, which follows from images in Fig. 4 analysis.

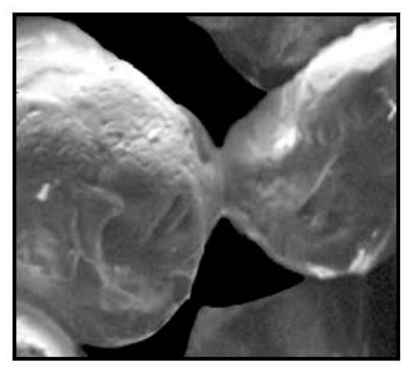

$a$

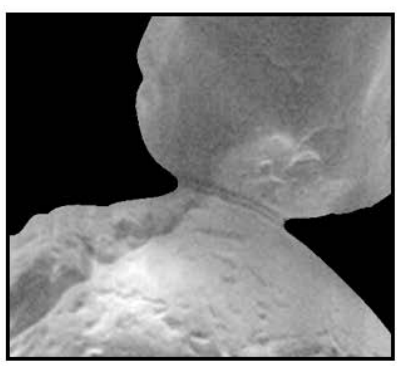

$b$

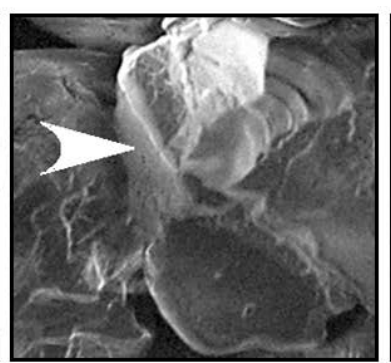

C

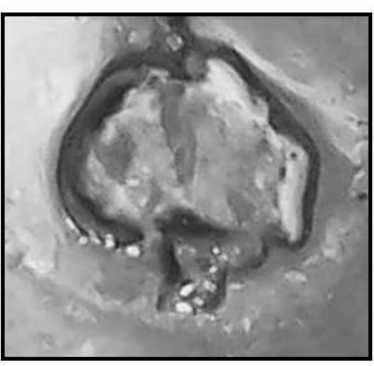

$d$

Fig. 4. Sodium silicate cuffs between spherical $(a, b)$ and flat $(c)$ surfaces (cuff is indicated by white arrow) of quartz sand adjacent grains in structured mixture, $\times 100$, view of destroyed cuff residual on sand grain surface with structured mixture mixed destruction character, $\times 300(d)$ 
It should be noted that SSS solidification with water of 55...65\% (by weight) content by microwave radiation has been accompanied by its foaming and foam structures of dehydrated sodium silicate $[14,15]$ forming. This, although it makes it possible to obtain CMC with high strength values, but requires manual or automated mixture compacting and is characterized by structured mixtures gas permeability low level. In case of SSSM structuring according to SMS-process, mixture compaction is carried out on vibrating table for $30 . .60$ sec, while ensuring structured mixture gas permeability at level of $170 . .230$ units and compressive strength of 1.0...1.5 MPa at SSS mass content in mixture of $0.5 \%$ and 4.2...5.6 MPa (see Fig. 3) - at $5 \%$ SSS.

Samples fracture surfaces appearances obtained using scanning electron and optical microscopes at $\times 20$ magnifications are shown in Fig. $5-9$.

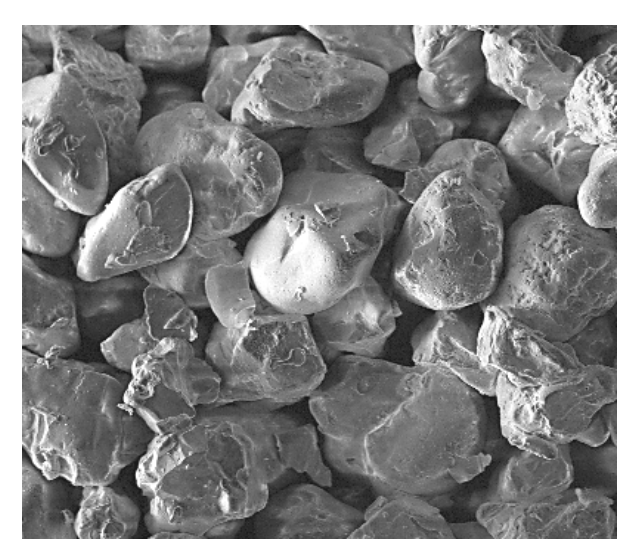

$a$

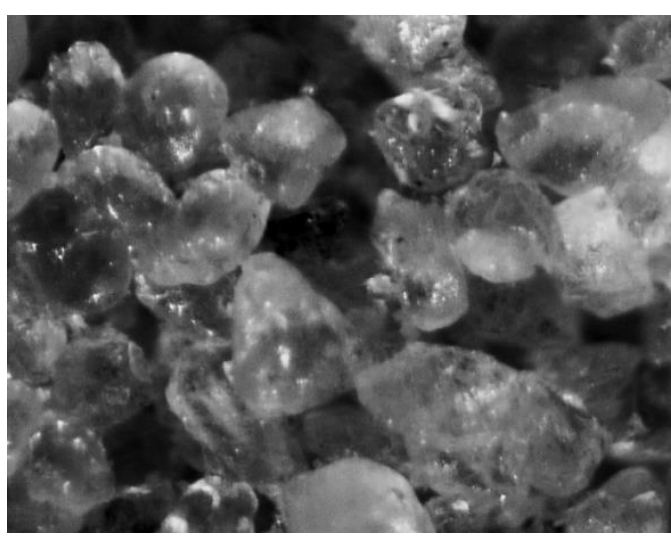

$b$

Fig. 5. Samples fracture surfaces appearances (predominantly cohesive fracture character, see point $A$ in Fig. 3) with SSS mass content of $0.5 \%$ (by weight), structured for 8 min by SMS-process, on scanning electron (a) and optical (b) microscopes, $\times 20$

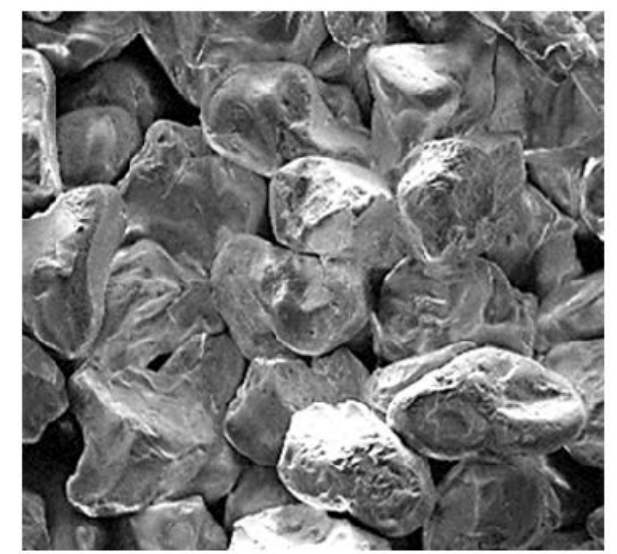

$a$

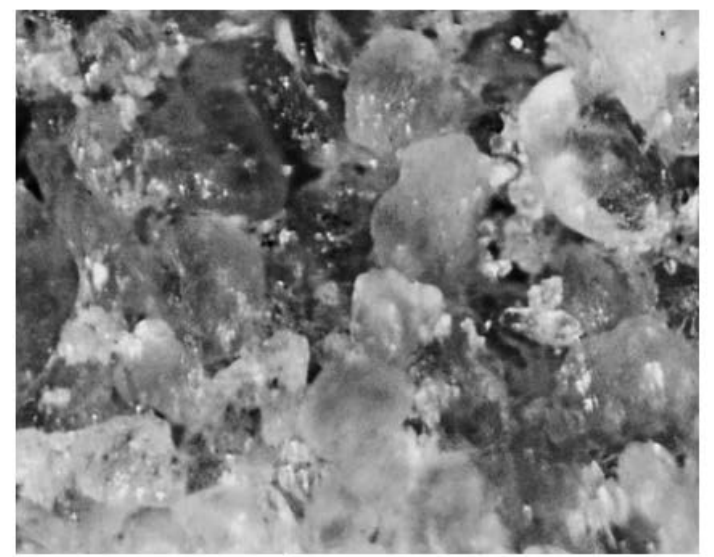

$b$

Fig. 6. Samples fracture surfaces appearances (predominantly cohesive fracture character, see point $B$ in Fig.3) with SSS mass content of $1.0 \%$ (by weight), structured for 4 min by SMS-process, on scanning electron (a) and optical $(b)$ microscopes, $\times 20$ 


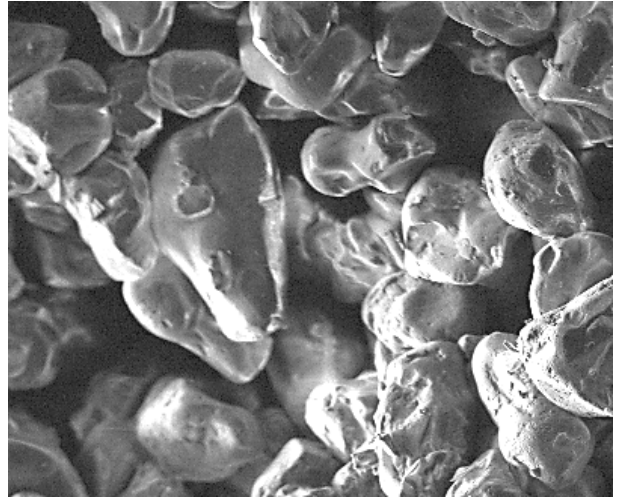

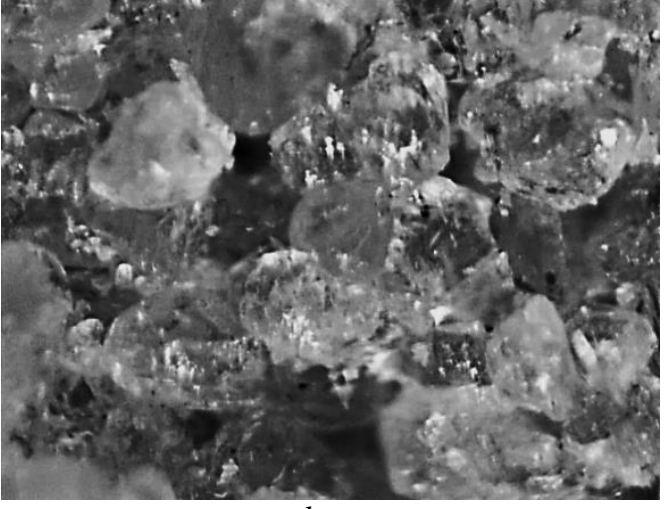

$b$

Fig. 7. Samples fracture surfaces appearances (cohesive-adhesive fracture character, see point $C$ in Fig. 3) with SSS mass content of 5.0 \% (by weight), structured for 4 min by SMS-process, on scanning electron ( $a$ ) and optical (b) microscopes, $\times 20$
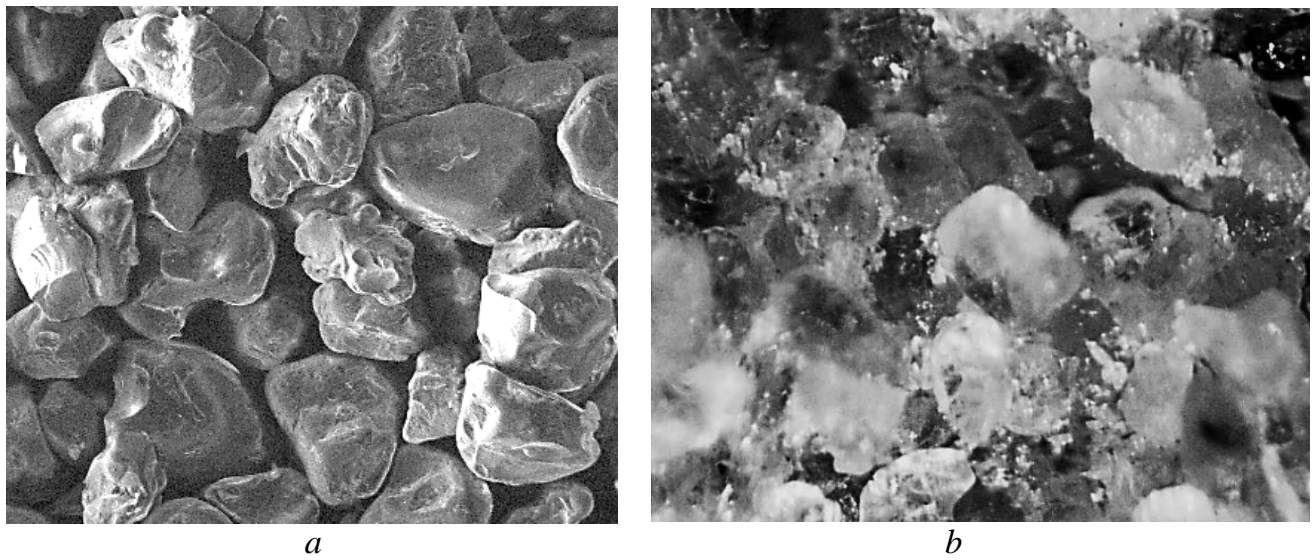

Fig. 8. Samples fracture surfaces appearances (predominantly adhesive fracture character, see point $D$ in Fig. 3) with SSS mass content of $1.0 \%$ (by weight), structured for 2 min by SMS-process, on scanning electron (a) and optical $(b)$ microscopes, $\times 20$
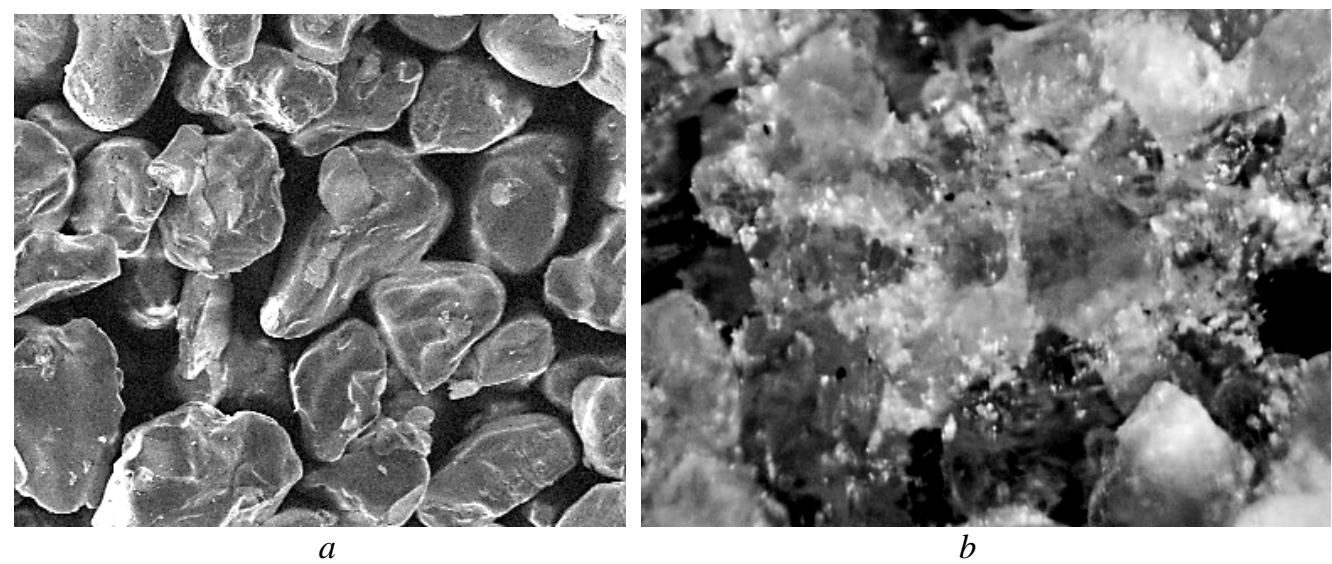

Fig. 9. Samples fracture surfaces appearances (adhesive fracture character, see point $K$ in Fig. 3) with SSS mass content of $5.0 \%$ (by weight), structured for 2 min by SMS-process, on scanning electron $(a)$ and optical (b) microscopes, $\times 20$ 
From Fig. 5- 9 analysis it follows that data on samples destruction character, obtained from theoretical studies [13] results, coincide with visual assessments results, which confirms dependence of destruction character on SSS mass content and samples time processing with microwave radiation by SMS-process.

\section{Conclusions}

With SSS mass content from 0.5 to $6.0 \%$ (by weight) for cladding quartz sand increasing, as well as with mixture by SMS-process treatment duration increasing, mixture ultimate strength in compression increases in close-to-exponential dependence. Structured mixture destruction character, in this case, does not depend on SSS content used for quartz sand cladding, but depends on SMS-process duration and with its time increasing changes from adhesive to mix or from adhesive to mixed and cohesive.

\section{Література}

1. Гурлев В.Г. Анализ физико-химических процессов формирования структуры жидкостекольных формовочных и стержневых смесей при производстве отливок, получаемых в разовых формах. Вестник ЮУрГУ. 2012. № 15. С. 11-19.

2. Жуковский С.С. Прочность литейной формы. М. : Машиностроение, 1989. 288 с.

3. Stachowicz M. Effect of overheating degree on activations efficiency of water-glass containing sand mix hardened by traditional drying. Archives of foundry engineering. 2015. Vol. 15, Issue 2. P. 77-82.

4. Carbonization and crushability of structured sand-sodium-silicate mixtures / L.I. Solonenko, R.V. Usenko, K.I. Uzlov, A.V. Dziubina, S.I. Repiakh. Naukovyi Visnyk Natsionalnoho Hirnychoho Universytetu. 2020. Vol. 5. P. 40-46.

5. Stachowicz M., Granat K. Research on reclamation and activation of moulding sand containing waterglass hardened with microwaves. Archives of foundry engineering. 2014. Vol. 14, Issue 2. P. 105-110.

6. Heating rate of granular inorganic materials by microwave radiation / L.I. Solonenko, O.P. Bilyi, S.I. Repiakh, T.V. Kimstach, K.I. Uzlov. Naukovyi Visnyk Natsionalnoho Hirnychoho Universytetu. 2020. № 2. P. 37-41.

7. Клюкова Т.Д., Власова К.А., Леонов А.А., Яшина С.А. Изучение механизма образования прочности в самотвердеющих смесях с фенольным связующим (обзор). Труды ВИАМ. 2018. № 3. С. $18-27$.

8. Жуковский С.С. Холоднотвердеющие связующие и смеси для литейных стержней и форм: справочник. М. : Машиностроение, 2010. 256 с.

9. Великанов Г.Ф., Примак Н.Н., Бречко А.А. Прочность формовочной смеси. Литейное производство. 1986. № 3. С. 10-12.

10. Лясс А.М. Быстротвердеющие формовочные смеси. М. : Машиностроение, 1965. 329 с.

11. Зыков А.П., Минаев Г.И. Механизм формирования прочностных свойств песчано-смоляных образцов из горячеплакированных смесей. Литейное производство. 1984. № 1. С. 15-16.

12. Великанов Г.Ф., Бречко А.А. Формовочные и стержневые смеси с заданными свойствами. Л. : Машиностроение, 1982. 214 с.

13. Солоненко Л.І., Білий О.П., Узлов К.І. Функціональні залежності між властивостями зразків 3 структурованих формувальних і стрижневих сумішей. Теорія і практика металургії. 2018. № 6. C. $93-100$.

14. Stachowicz M., Granat K., Palyga L. Influence of sand preparation on properties of chromite moulding sands with sodium silicate hardened with selected methods. Archives of metallurgy and materials. 2017. Vol. 62, Issue 1. P. 379-383.

15. Stachowicz M. Preliminary testing of microwave-cured joints made of adhesives based on hudrated sodium silicate and quartz sand. Transactions of the foundry research institute. 2018. Vol. 58, Issue 4. P. 295-308.

\section{References}

1. Gurlev, V.G. (2012). Analysis of physical and chemical processes of structure formation of liquid glass molding and core mixtures in dispensable mold casting. Bulletin of the South Ural State University, 15, 11-19.

2. Zhukovsky, S.S. (1989). Mold strength. Moscow: Mashinostroenie.

3. Stachowicz, M. (2015). Effect of overheating degree on activations efficiency of water-glass containing sand mix hardened by traditional drying. Archives of foundry engineering, 15, 2, 77-82. 
4. Solonenko, L.I., Usenko, R.V., Uzlov, K.I., Dziubina, A.V., \& Repiakh, S.I. (2020). Carbonization and crushability of structured sand-sodium-silicate mixtures. Naukovyi Visnyk Natsionalnoho Hirnychoho Universytetu, 5, 40-46.

5. Stachowicz, M., \& Granat, K. (2014). Research on reclamation and activation of moulding sand containing water-glass hardened with microwaves. Archives of foundry engineering, 14, 2, 105-110.

6. Solonenko, L.I., Bilyi, O.P., Repiakh, S.I., Kimstach, T.V., \& Uzlov, K.I. (2020). Heating rate of granular inorganic materials by microwave radiation. Naukovyi Visnyk Natsionalnoho Hirnychoho Universytetu, 2, 37-41.

7. Klyukova, T.D., Vlasova, K.A., Leonov, A.A., \& Yashina, S.A. (2018). Study of the mechanism of strength formation in self-hardening mixtures with a phenolic binder (review). VIAM Proceedin, 3, 1827.

8. Zhukovsky, S.S. (2010). Cold-hardening binders and mixtures for casting cores and molds: a reference book. Moscow: Mashinostroenie.

9. Giants, G.F., Primak, N.N., \& Brechko, A.A. (1986). The strength of the sand. Foundry, 3, 10-12.

10. Lyass, A.M. (1965). Fast-setting molding sands. Moscow: Mashinostroenie.

11. Zykov, A.P., \& Minaev, G.I. (1984). Mechanism of Formation of Strength Properties of Sand-Resin Samples from Hot-Clad Mixes. Foundry, 1, 15-16.

12. Giants, G.F., \& Brechko, A.A. (1982). Molding and core mixtures with desired properties. Leningrad: Mashinostroenie.

13. Solonenko, L.I., Biliy, O.P., \& Uzlov, K.I. (2018). Functional dependencies between sample properties from structured molding and core mixtures. Theory and practice, 6, 93-100.

14. Stachowicz, M., Granat, K., \& Palyga, L. (2017). Influence of sand preparation on properties of chromite moulding sands with sodium silicate hardened with selected methods. Archives of metallurgy and materials, 62, 1, 379-383.

15. Stachowicz, M. (2018). Preliminary testing of microwave-cured joints made of adhesives based on hudrated sodium silicate and quartz sand. Transactions of the foundry research institute, 58, 4, 295-308.

Солоненко Людмила Ігорівна; Solonenko Lyudmila, ORCID: https://orcid.org/0000-0003-2092-8044

Реп'ях Сергій Іванович; Repyakh Sergei, ORCID: https://orcid.org/0000-0003-0203-4135

Узлов Костянтин Іванович; Uzlov Kostiantyn, ORCID: https://orcid.org/0000-0003-0744-9890

Кімстач Тетяна Володимирівна; Kimstach Tetiana, ORCID: https://orcid.org/0000-0002-8993-201X 